\title{
The Effect of Cash, Vouchers, and Food Transfers on Intimate Partner Violence: Evidence from a Randomized Experiment in Northern Ecuador
}

\author{
By Melissa Hidrobo, Amber Peterman, and Lori Heise*
}

\begin{abstract}
Using a randomized experiment in Ecuador, this study provides evidence on whether cash, vouchers, and food transfers targeted to women and intended to reduce poverty and food insecurity also affected intimate partner violence. Results indicate that transfers reduce controlling behaviors and physical and/or sexual violence by 6 to 7 percentage points. Impacts do not vary by transfer modality, which provides evidence that transfers not only have the potential to decrease violence in the short-term, but also that cash is just as effective as in-kind transfers. (JEL I38, J16, K42, O15, O17)
\end{abstract}

\section{$\mathbb{R}$}

ecent multicountry studies show that intimate partner violence (IPV) is widespread and common. One in three women globally have experienced physical and/or sexual violence by a partner during their lifetime (Devries et al. 2013, World Health Organization (WHO) 2013). In Ecuador, the country examined in this analysis, the lifetime prevalence of IPV is estimated at 35 percent for physical violence, 14.5 percent for sexual violence, and 43.4 percent for psychological violence (Instituto Nacional de Estadística y Censos (INEC) 2011). Although regional variation exists across provinces within Ecuador, as well as within and between countries globally, the prevalence of IPV remains high in most parts of the world.

While the consequences of IPV are well documented, there is less evidence on policies and programs that are effective at reducing IPV in the developing world (Ellsberg et al. 2015). Many development programs aim at empowering women through economic means such as labor, assets, microfinance, or cash transfers (CTs). Yet, across and within disciplines as varied as sociology, psychology, and economics, there is no consensus on the theories and predicted association between female

\footnotetext{
*Hidrobo: International Food Policy Research Institute, 2033 K Street, NW, Washington, DC 20006 (e-mail: m.hidrobo@cgiar.org); Peterman: UNICEF Office of Research-Innocenti, Piazza S.S. Annunizata 12, 50121 Florence, Italy (e-mail: apeterman@ @unicef.org); Heise: London School of Hygiene and Tropical Medicine, Keppel Street, London WC1E 7HT, UK (e-mail: Lori.Heise@1shtm.ac.uk). We are grateful to the Centro de Estudios de Población y Desarrollo Social (CEPAR) for assistance in data collection and to the World Food Programme (WFP) (Rome and Quito) for excellent collaboration and program implementation and in particular to Deborah Hines, Marcelo Moreano, Luis Fernandez, Veronica Molina, Ines Lopez, Carmen Galarza, and Luis Romero. We would like to thank John Hoddinott, Ana Buller, Erin Fletcher, Amy Margolies, Tia Palermo, Dan Gilligan, and all seminar participants at IFPRI, SVRI Forum, LACEA, and NEUDC for helpful comments. We gratefully acknowledge funding from the Government of Spain received through the World Food Programme; the International Initiative for Impact Evaluation (3ie), the CGIAR Research Program on Policies, Institutions and Markets; and an anonymous donor. All errors are our own.

Go to http://dx.doi.org/10.1257/app.20150048 to visit the article page for additional materials and author disclosure statement(s) or to comment in the online discussion forum.
} 
economic empowerment and IPV (Heise 2012). The contribution of economics on the relationship between a woman's income and IPV has been fairly recent and depends on how violence is modeled in household bargaining models. In classic bargaining models, individual control of resources matters because bargaining outcomes depend on threat points such as divorce (Manser and Brown 1980, McElroy and Horney 1981) or noncooperative equilibriums (Lundberg and Pollak 1993). The more promising an individual's opportunities are outside the household, the more credible the threat point, and therefore, the more likely that the intra-household distribution of resources will align more closely with that individual's preferences. In these bargaining models, when violence is expressive and used to release frustration, an increase in a woman's income decreases violence by improving her threat point and thus her bargaining power within the household (Farmer and Tiefenthaler 1997). However, when violence is either instrumental and used to control the victim's behavior or allocation of resources within the household (Eswaran and Malhotra 2011; Tauchen, Witte, and Long 1991), or extractive and used to extract monetary transfers from the victim or her family (Bloch and Rao 2002), an increase in her income may increase violence.

Given the lack of consensus on theories related to a woman's income and IPV, it is no surprise that the empirical evidence is also mixed. To add to the ambiguity, few studies have accounted for the endogeneity of economic status or income, and thus most of the evidence consists of basic associations that tell us little about the causal mechanisms. The few studies that have attempted to account for the endogeniety of income or economic status have used exogenous variation in either demand or supply of labor (Aizer 2010, Chin 2012) or randomized allocation of microfinance (Pronyk et al. 2006), and have found a negative relationship between a woman's economic status and IPV.

Building off a robust literature on the social impacts of CT programs, a number of recent papers have examined linkages between CTs and IPV. Although the details of program design vary, all such programs transfer monetary resources to poor households, and in the vast majority of cases, transfers are made to women because they are more likely to reinvest resources into the family's well-being (Thomas 1997, Quisumbing and Maluccio 2000, Hoddinott and Haddad 1995). In general, studies have found decreases in physical violence that range from 5 to 11 percentage points, although some subgroups are found at greater risk for an increase in violence (Angelucci 2008; Bobonis, González-Brenes, and Castro 2013; Hidrobo and Fernald 2013; Haushofer and Shapiro 2013; Perova and Vakis 2013).

Using a randomized experiment conducted in 2011 in Northern Ecuador, this study evaluates whether cash, vouchers, and food transfers targeted to women and intended to reduce poverty and food insecurity among the urban poor, also impact IPV. Comparison of the three transfer modalities — cash, vouchers, or food—is novel and contributes to the existing literature by providing evidence on whether the mode of transfer matters to impact. While a companion study (Hidrobo et al. 2014) finds that the transfer modalities were infra-marginal ${ }^{1}$ and thus had similar impacts on the

\footnotetext{
${ }^{1}$ Economic theory predicts that cash and in-kind transfers of equal size will have similar impacts on a household's utility and consumption if the value of the in-kind transfer is less than what a household would have spent on that particular good ("infra-marginal") and if there are no transaction costs.
} 
value of food, nonfood, and total consumption, differences across modalities could emerge in who controls the transfer or the likelihood of it being commandeered by one partner. Descriptive statistics suggest that food is significantly more likely to be controlled by the female spouse than cash or vouchers (60 percent for food compared to 50 percent and 48 percent for cash and voucher, respectively), while cash and vouchers are significantly more likely to be controlled by household head and spouse together. Moreover, there are restrictions on how transfers can be used that vary by modality. The food transfer, which is composed mainly of staple goods, is expected to be consumed by the household and thus presents little opportunity for generating conflict within the household. ${ }^{2}$ Similarly, the food voucher is redeemable for only a predetermined list of nutritious foods at a specified supermarket within each urban center. The voucher is nontransferable and thus cannot be extracted and used for anything other than the preapproved list of food items by the cardholder. Cash, on the other hand, can be spent without restrictions and thus has more opportunity to lead to conflict over its use. Consequently, if partners use IPV as a tool to extract resources or control the allocation of resources within the household, then we would expect to observe differences in impact across cash and the other modalities.

Consistent with evidence on IPV from other studies, we find that transfers decrease the probability that women experience controlling behaviors and physical and/or sexual violence by 6 to 7 percentage points (or approximately a 19 to 30 percent decrease). This effect does not vary significantly by treatment modality, which suggests that violence is not being used to forcefully extract resources. We explore potential mechanisms through which transfers decrease violence and find evidence that transfers change expenditure patterns which likely indicates changes in intra-household bargaining; increase time spent on household chores by both husband and wife which may signal increased marital cohesion; and reduce poverty which likely reduces poverty-related stress and conflict.

\section{Study Design and Data}

\section{A. The Program}

In April 2011, the World Food Programme (WFP) expanded its assistance to address the food security and nutrition needs of Colombian refugees and poor Ecuadorians, and to support the integration of refugees into Ecuadorian communities. The new program was designed as a randomized control trial (RCT) and consisted of six monthly transfers of cash, vouchers, or food to Colombian refugees and poor Ecuadorian households. In addition to improving the food consumption of poor households, a goal of the program was to improve the role of women in household

\footnotetext{
${ }^{2}$ Although it is possible that food could be extracted and sold for cash, there is little evidence that this occurred in this study.
} 
decision making, particularly related to food and nutrition. Consequently, the program specifically targeted women within households. ${ }^{3}$

The program was implemented in seven urban centers with large Colombian refugee populations in the provinces of Carchi and Sucumbíos in Northern Ecuador. To determine program qualification, all households within the pre-chosen neighborhoods 4 were mapped and administered a short census survey. Households were ranked according to a proxy means test based on asset ownership, employment, food security, demographics, and nationality and a cut off score to determine program eligibility was implemented based on project budget constraints 5

Participating households received benefits from April 2011 to September 2011. The value of the monthly transfer was standardized across all treatment arms and was equivalent to $\$ 40$ per month per household for a total of $\$ 240$ over the six month study period. The monthly value was approximately 11 percent of a household's pre-transfer monthly consumption. The food transfer contained rice (24 kilograms $(\mathrm{kg})$ ), lentils $(8 \mathrm{~kg})$, vegetable oil (4 liters), and canned sardines (8 cans each $0.425 \mathrm{~kg}$ ). The food voucher was redeemable at local supermarkets for a preapproved list of nutritious foods. The cash was distributed though preprogrammed ATM cards. The transfers were conditional on attendance of monthly nutrition trainings, which were standardized across treatment arms. The timing of disbursement, frequency, and value of transfers were equalized across modalities to ensure that differences in outcomes were attributable to the modality and not to other confounding factors.

\section{B. Study Design}

The program evaluation was based on random assignment of the intervention. Due to the differences in socioeconomic and geographic characteristics of the study provinces, Sucumbíos and Carchi, the randomization was stratified at the province level. Randomization was conducted in two stages: first neighborhoods within the urban centers were randomized to either treatment or control groups (see Figure B.1 in the online Appendix); and second, clusters within the treatment neighborhoods were randomized to either cash, vouchers, or food. The two-stage randomization was done to ensure that households in control neighborhoods were in geographically distinct locations from those in treatment neighborhoods to help mitigate possible discontent among neighbors not receiving the transfer. In total, 80 neighborhoods and 145 clusters were randomized into the four intervention arms-control, cash, vouchers, and food.

\footnotetext{
${ }^{3}$ Although the program was targeted to women, men were also allowed to participate if there was not a qualifying adult woman in the household at the time of enrollment. Among all beneficiary households, approximately 79 percent of registered beneficiary cardholders in Carchi and 73 percent of registered beneficiary cardholders in Sucumbíos were women (WFP-Ecuador 2011).

${ }^{4}$ Neighborhoods are administrative units within the urban centers and typically headed by presidents with oversight on social services and other administrative functions.

${ }^{5}$ Based on point scores by nationality, the decision was made to automatically enroll all Colombian and mixed-nationality households. In addition, households were excluded from eligibility if they were current recipients of the government's social safety net, the Bonode Desarrollo Human (BDH), which targeted poor households with school age and young children.
} 
In order to evaluate the transfer program, baseline (March 2011) and endline surveys (October to November 2011) were conducted. In total, 2,357 households were surveyed at baseline before the start of the transfer program and 2,122 at endline after the last transfers were distributed. Household surveys collected information on household characteristics, demographics, food consumption, labor, education, and health. The survey also collected detailed information on women's status in the household, household decision making, and IPV. Further details about the study design, sampling strategy, and intervention can be found in Hidrobo et al. (2012, 2014).

\section{Violence Variables}

Violence indicators were collected in accordance with the WHO protocol on ethical guidelines for conducting research on IPV (WHO 2001).6 To be eligible for interview of the IPV module, women had to be 15 years or older, been in a relationship in the last six months, and be either the household head or partner of the household head. Only women who could be interviewed in private were administered the IPV module 7

In order to elicit accurate assessments of violence, we administered multiple behaviorally specific questions on a range of abusive acts, a technique shown to maximize disclosure (Ellsberg et al. 2001). Indicators of internationally validated standardized IPV measures from the WHO Violence Against Women Instrument (Ellsberg and Heise 2005; Straus 1979; Hindin, Kishor, and Ansara 2008) were administered and included three types of violence (physical, sexual, emotional) and controlling behaviors. To correspond with the length of the transfer period, we asked about violent acts experienced over the past six months as well as any violence experienced by the respondent in her lifetime.

Following WHO and Demographic and Health Survey (DHS) protocol, we construct binary indicators for the following three behaviors experienced in the last six months: controlling behaviors, emotional violence, and physical and/or sexual violence. In the endline survey there are six questions that are categorized as "emotional violence," four that are categorized as "controlling behavior," seven that are categorized as "physical violence," and two that are categorized as "sexua! violence" (see Appendix Table A.1 for questions and corresponding categories). ${ }^{8}$ For controlling behaviors and emotional violence, we create indicators that equal one if the respondent answered yes to any of the corresponding violence questions within each category in the last six months. For physical and/or sexual violence we create an indicator that equals one if the respondent answered yes to any of the seven physical violence questions or any of the two sexual violence questions.

\footnotetext{
${ }^{6}$ In particular, we ensured adequate training of interviewers, enacted safety measures that guaranteed privacy during interviews, and interviewed only one woman per household to ensure that no other household member was aware that survey questions involved disclosing IPV. In addition, enumerators provided all women with disguised contact information for local IPV support services for referral, regardless of disclosure of IPV.

${ }^{7}$ If a woman was not alone at the time of the interview enumerators were instructed to either find a place where they could be alone, or to come back to the household at another time when the woman would be alone. If neither of these two options were feasible, then the woman was not administered the IPV module.

${ }^{8}$ The baseline survey only had two questions on controlling behaviors and three on emotional violence.
} 


\section{Study Sample and Attrition}

Of the 2,357 households interviewed at baseline, 2,064 had a female head of household or spouse eligible to be administered the household decision making or IPV module (Figure 1). From these households, we restrict our analysis to women 15-69 years old who are married or in unions at baseline, for a total of 1,433 women. ${ }^{9}$ Of the 1,433 women 15 to 69 -years-old in relationships at baseline, 1,413 (or 98.6 percent) were alone at the time of the interview and thus administered the IPV module. Of these women, 1,261 were resurveyed at endline and 1,226 were alone at the time of the interview and in a relationship, and thus administered the IPV module. Thus, the sample for this analysis consists of 1,226 women who are head of household or spouse, ages 15 to 69 years and in a relationship at baseline, with baseline and endline data on IPV.

Of the eligible baseline sample of 1,433 women aged 15-69 years in a relationship, 85.6 percent were administered the IPV questionnaire at baseline and endline. While most of the attrition is due to not finding the same household or woman from baseline to endline, 4 percent is due to a woman not being alone at the time of the interview (either at baseline or endline) or not being in a relationship at endline. If attrition is correlated with treatment assignment, then this could potentially bias the estimates of the impact of a transfer on IPV. As Table 1 and online Appendix Table B.1 reveal, there are no significant differences in attrition rates between the control arm and any of the treatment arms. Although attrition rates are similar across arms, differential attrition in characteristics across treatment and control arms could threaten the internal validity of the study. Appendix Table A.2 reveals that with the exception of the indicator for not having a room exclusively for sleeping, there are no significant differences in baseline characteristics for those who attrited across treatment and control arms.

\section{E. Baseline Analysis}

To ensure that the success of the initial randomization still holds for the sample of 1,226 women used in this analysis, we compare baseline characteristics across treatment and control women. Table 1 shows that randomization was largely effective at balancing baseline characteristics. Across 21 difference-in-means tests between treatment and control women, only two are statistically different at the 5 percent level. In particular, women in the control group have significantly more children aged 6-15 years old and are significantly less likely to have experienced physical and/or sexual violence from their partner at baseline. While this imbalance in our outcome variable would most likely lead to an underestimate of our impact results, our empirical specifications minimize any bias by controlling for baseline levels of violence. Similar balance tests are conducted across the control arm and each treatment arm, and again, show that randomization was in general successful

\footnotetext{
${ }^{9}$ We exclude women over the age of 69 (18 observations) because IPV is rare among this age group. Although IPV decreases with age, we do not restrict our sample to the more common age range of 15-49 years because we are interested in the impact on program participants and not a subsample of participants.
} 


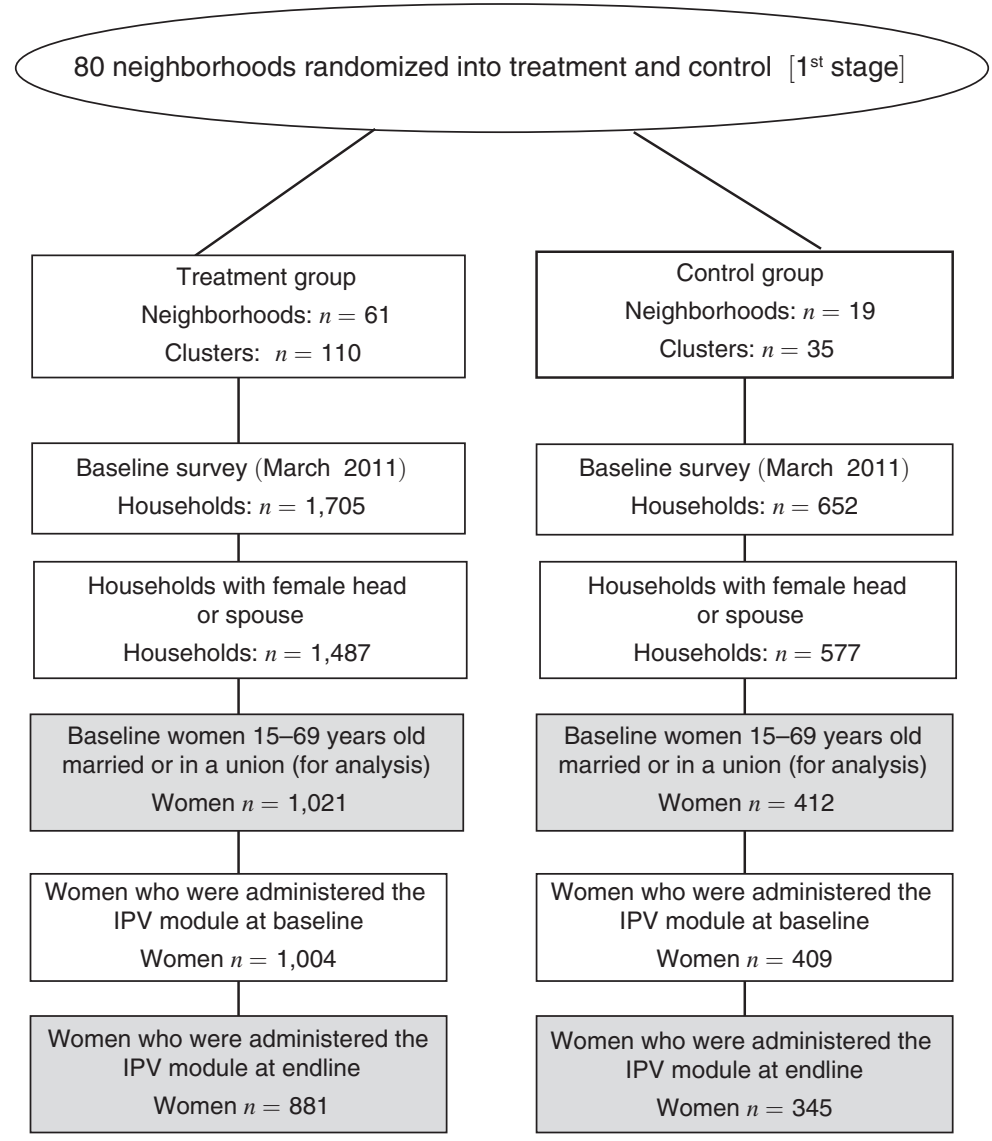

Figure 1: Flow of Participants and Randomization

(online Appendix Table B.1). Across $126(21 \times 6)$ difference-in-means tests, 3 are statistically different at the 5 percent level. With respect to the outcome variable, the significant difference seen in Table 1 for physical and/or sexual violence is mainly due to a significant difference between the voucher arm and the control arm.

Table 1 also reveals that the baseline prevalence of IPV is high among the study sample, with 16 percent of women experiencing physical and/or sexual violence and 26 percent experiencing emotional violence in the previous six months. Similar to the national prevalence rate of 35 percent for lifetime physical violence, the lifetime prevalence rate of physical and/or sexual violence in our sample is 35 percent.

\section{Methodology}

To estimate the impact of transfers on IPV, we take advantage of the randomized experimental design and conduct an intent-to-treat (ITT) analysis. This approach avoids bias that may occur due to selection into and out of the program. Moreover, we estimate the treatment effect using Analysis of Covariance (ANCOVA), which 
Table 1-Baseline Means by Pooled Treatment and Control Groups

\begin{tabular}{|c|c|c|c|c|c|}
\hline & Observations & All & Control & Treatment & $\begin{array}{l}p \text {-value } \\
\text { of diff. }\end{array}$ \\
\hline Attrition rate & 1,433 & 0.14 & 0.16 & 0.14 & 0.31 \\
\hline \multicolumn{6}{|l|}{ Female characteristics } \\
\hline Head of household & 1,226 & 0.02 & 0.03 & 0.02 & 0.15 \\
\hline Born in Colombia & 1,226 & 0.36 & 0.39 & 0.34 & 0.40 \\
\hline Age & 1,226 & 34.84 & 35.29 & 34.66 & 0.43 \\
\hline Some secondary education or higher & 1,226 & 0.38 & 0.38 & 0.39 & 0.87 \\
\hline Married & 1,226 & 0.42 & 0.42 & 0.43 & 0.83 \\
\hline Indigenous & 1,226 & 0.04 & 0.03 & 0.04 & 0.53 \\
\hline Afro-Ecuadorian & 1,226 & 0.07 & 0.06 & 0.07 & 0.66 \\
\hline Worked in the last six months & 1,226 & 0.32 & 0.31 & 0.33 & 0.56 \\
\hline Sole owner of house & 1,226 & 0.05 & 0.04 & 0.05 & 0.44 \\
\hline \multicolumn{6}{|l|}{ Partner Characteristics } \\
\hline Partner has some secondary education or higher & 1,226 & 0.38 & 0.36 & 0.39 & 0.42 \\
\hline Partner's age & 1,226 & 38.62 & 39.20 & 38.39 & 0.33 \\
\hline Partner was employed in the last six months & 1,226 & 0.96 & 0.96 & 0.96 & 0.66 \\
\hline Partner's hours worked in a typical week & 1,226 & 46.58 & 47.27 & 46.32 & 0.57 \\
\hline \multicolumn{6}{|l|}{ Household Characteristics } \\
\hline Number of children $0-5$ years old in household & 1,226 & 0.75 & 0.72 & 0.75 & 0.52 \\
\hline Number of children $6-15$ years old in household & 1,226 & 0.92 & 1.02 & 0.87 & 0.05 \\
\hline Value of total monthly consumption per capita (USD) & 1,222 & 106.60 & 107.32 & 106.31 & 0.86 \\
\hline House does not have rooms exclusively for sleeping & 1,226 & 0.15 & 0.13 & 0.15 & 0.37 \\
\hline Lifetime physical and/or sexual violence & 1,226 & 0.35 & 0.33 & 0.35 & 0.64 \\
\hline Controlling behaviors & 1,226 & 0.17 & 0.17 & 0.17 & 0.87 \\
\hline Emotional violence & 1,226 & 0.26 & 0.24 & 0.27 & 0.36 \\
\hline Physical and/or sexual violence & 1,226 & 0.16 & 0.12 & 0.18 & 0.05 \\
\hline$p$-value from joint $F$-test & & & & & 0.16 \\
\hline
\end{tabular}

Notes: $p$-values are reported from Wald tests on the equality of means of pooled treatment and control for each variable. Comparison of means for female characteristics, partner characteristics, household characteristics, and IPV are conducted on the sample of women in the analysis with both baseline and endline data. Standard errors are clustered at the cluster level.

controls for the lagged outcome variable. ANCOVA estimates are preferred to difference-in-differences estimates when the autocorrelation of outcomes is low (McKenzie 2012). Intuitively, if autocorrelation is low, then difference-in-differences estimates will overcorrect for baseline imbalances. ANCOVA estimates, on the other hand, will adjust for baseline imbalances according to the degree of correlation between baseline and endline and lead to a more efficient estimation of impact. Given that the autocorrelation between baseline and endline of our IPV outcomes are low (between 0.27 and 0.35 ) and that the indicators of interest are binary, we estimate the following ANCOVA probit model for pooled treatment:

$$
\operatorname{Prob}\left(Y_{i j 1}=1\right)=\Phi\left(\propto+\beta_{T} \text { Treat }_{j}+\gamma Y_{i j 0}+\delta P_{i j}\right)
$$

where $Y_{i j 1}$ is the IPV outcome of interest for woman $i$ from cluster $j$ at endline and $Y_{i j 0}$ is the IPV outcome of interest at baseline. As previously mentioned, our outcomes are measures of: controlling behaviors, emotional violence, and physical and/or sexual violence. $\Phi$ is the cumulative distribution function of the standard normal distribution. Treat $_{j}$ is an indicator that equals 1 if cluster $j$ is in any treatment arm, and $\beta_{T}$ represents the ITT estimator, or the effect of being assigned to any 
treatment arm. $P_{i j}$ is an indicator for Carchi province, which is the level of stratification. In all regressions we adjust standard errors for clustering at the cluster level, which was the level of randomization.

Given the relative success of the random assignment, the inclusion of baseline controls is not necessary to obtain unbiased estimates of $\beta$. For most estimates, however, we account for baseline socioeconomic characteristics in order to increase the precision of the estimates and control for any minor differences between treatment and control arms at baseline. The extended baseline control variables are: female characteristics (whether the women is head of household, whether she is married, whether she has secondary education, whether she is Colombian, whether she is indigenous, whether she is Afro-Ecuadorian, whether she is employed, whether she owns the house, and her age); partner characteristics (whether partner has secondary education, his age); and household characteristics (number of children 0-5 years old, number of children 6-14 years old, wealth quartiles).

To estimate whether the impact on IPV varied by modality, we estimate the following ANCOVA probit model:

$$
\operatorname{Prob}\left(Y_{i j 1}=1\right)=\Phi\left(\propto+\beta_{f} \text { food }_{j}+\beta_{c} \text { cash }_{j}+\beta_{v} \text { voucher }_{j}+\gamma Y_{i j 0}+\delta P_{i j}\right) .
$$

The indicators food $_{j}$, cash $_{j}$, and voucher $_{j}$ are equal to 1 if cluster $j$ is in the corresponding treatment arm. Coefficients $\beta_{f}, \beta_{c}, \beta_{v}$ represent the ITT estimators, or the effect of being assigned to the specific treatment arm. To test whether the estimators are statistically different by treatment arm, we conduct tests of equality and report the $p$-values.

\section{Results}

\section{A. Impact of Pooled Treatment}

Table 2 presents estimates (equation 1) of the pooled treatment on IPV outcomes. For each outcome, the first column presents mean differences without any controls, the second column presents coefficients controlling only for the level of stratification (or province) and baseline outcome variable, and the third column includes the full set of extended control variables. Coefficients from probit models are converted to marginal effects evaluated at the mean of the independent variable. Table 2 reveals that there are significant program impacts leading to decreases in controlling behaviors and physical and/or sexual violence ranging from 6 to 7 percentage points. Compared to the means of the control group at endline, these are decreases ranging from 19 percent for controlling behaviors to 30 percent for physical and/or sexual violence. There are no significant impacts on emotional violence. In all cases, the inclusion of control variables has very little impact on the size or significance of coefficients.

As a complement to the aggregate IPV measures, we also examine impacts disaggregated by individual question used to construct the IPV measures (Table 3). Results indicate a negative and significant impact on the following six indicators: accused her of being unfaithful; limited her contact with friends and family; humiliated or insulted her; pushed, shook, or threw something at her; slapped or twisted 
Table 2-Impact of Pooled Treatment on Aggregate IPV Measures

\begin{tabular}{lcccc}
\hline \hline & $\begin{array}{c}\text { Endline } \\
\text { control mean } \\
(1)\end{array}$ & $\begin{array}{c}\text { No controls } \\
(2)\end{array}$ & $\begin{array}{c}\text { Basic controls } \\
(3)\end{array}$ & $\begin{array}{c}\text { Extended } \\
\text { controls } \\
(4)\end{array}$ \\
\hline Controlling behaviors & 0.36 & -0.07 & -0.06 & -0.07 \\
& & $(0.03)$ & $(0.03)$ & $(0.03)$ \\
Emotional violence & 0.35 & -0.04 & -0.04 & -0.04 \\
Physical and/or sexual violence & & $(0.04)$ & $(0.03)$ & $(0.03)$ \\
& 0.20 & -0.04 & -0.06 & -0.06 \\
\end{tabular}

Notes: For each IPV measure listed, treatment effects of pooled treatment are reported in columns $2-4$. Standard errors in parentheses are clustered at the cluster level. Basic controls include baseline value of the outcome variable and dummy for province stratum. Extended controls include baseline female characteristics (whether the woman is head of household, whether she is married, whether she has secondary education, whether she is Colombian, whether she is indigenous, whether she is Afro-Ecuadorian, whether she is employed, whether she owns the house, and her age); partner characteristics (whether partner has secondary education, his age); household characteristics (number of children 0-5 years old, number of children 6-14 years old, wealth quartiles); baseline value of outcome variable, and dummy for province stratum. Observations $=1,226$.

her arm; and tried to choke or burn her. Experience of severe physical (threatening or attacking with a weapon) and sexual violence in the last six months is rarely reported in our sample, and thus, it is no surprise that we find no impact on these individual indicators.

\section{B. Impact by Treatment Modality}

Table 4 explores whether there are differences in impact across modalities (equation 2). Similar to estimates in Table 2, we present marginal effects with no control variables, basic control variables, and a full set of control variables. $p$-values from tests of differences on the size of impact across modalities are presented at the bottom of each panel. We find that food transfers result in significant and negative impacts on physical or sexual violence; cash results in significant and negative impacts on controlling behaviors; and vouchers result in significant and negative impacts on controlling behaviors and physical and/or sexual violence. Impacts for these three outcomes are similar in magnitude to the pooled treatment effect, ranging from 6 to 8 percentage point reductions. Differences across modalities are small and range from 0 to 3 percentage points in the most robust models. As shown by the $p$-values testing differences across modalities, the impacts across transfer modality are not statistically distinguishable from each other. ${ }^{10}$

\footnotetext{
${ }^{10}$ Although power calculations were conducted on the full sample of households and not the subsample of women eligible for the IPV module, differences across modalities are so small, that to detect these impacts samples of over 100,000 per arm would be needed.
} 
Table 3-Impact of Pooled Treatment on Individual IPV Indicators

\begin{tabular}{|c|c|c|c|c|}
\hline & $\begin{array}{c}\text { Endline } \\
\text { control mean } \\
(1)\end{array}$ & $\begin{array}{c}\text { No } \\
\text { controls } \\
(2)\end{array}$ & $\begin{array}{c}\text { Basic } \\
\text { controls } \\
(3)\end{array}$ & $\begin{array}{c}\text { Extended } \\
\text { controls } \\
(4)\end{array}$ \\
\hline \multicolumn{5}{|l|}{ Panel A. Controlling behaviors } \\
\hline Accused you of being unfaithful & 0.16 & $\begin{array}{c}-0.04 \\
(0.02)\end{array}$ & $\begin{array}{r}-0.04 \\
(0.02)\end{array}$ & $\begin{array}{r}-0.04 \\
(0.02)\end{array}$ \\
\hline Tried to limit your contact with your family & 0.16 & $\begin{array}{c}-0.04 \\
(0.02)\end{array}$ & $\begin{array}{r}-0.04 \\
(0.02)\end{array}$ & $\begin{array}{r}-0.05 \\
(0.02)\end{array}$ \\
\hline Tried to limit your contact with friends & 0.17 & $\begin{array}{c}-0.04 \\
(0.03)\end{array}$ & $\begin{array}{r}-0.04 \\
(0.02)\end{array}$ & $\begin{array}{r}-0.04 \\
(0.02)\end{array}$ \\
\hline Wanted to know where you were at all times & 0.24 & $\begin{array}{c}-0.03 \\
(0.03)\end{array}$ & $\begin{array}{c}-0.03 \\
(0.03)\end{array}$ & $\begin{array}{r}-0.02 \\
(0.03)\end{array}$ \\
\hline \multicolumn{5}{|l|}{ Panel B. Emotional violence } \\
\hline Humiliated or insulted you & 0.26 & $\begin{array}{c}-0.05 \\
(0.03)\end{array}$ & $\begin{array}{r}-0.06 \\
(0.03)\end{array}$ & $\begin{array}{r}-0.06 \\
(0.03)\end{array}$ \\
\hline Threatened to leave you & 0.15 & $\begin{array}{c}-0.00 \\
(0.02)\end{array}$ & $\begin{array}{r}-0.00 \\
(0.02)\end{array}$ & $\begin{array}{r}-0.00 \\
(0.02)\end{array}$ \\
\hline Threatened to take away your children & 0.08 & $\begin{array}{c}0.01 \\
(0.02)\end{array}$ & $\begin{array}{c}0.01 \\
(0.02)\end{array}$ & $\begin{array}{c}0.01 \\
(0.02)\end{array}$ \\
\hline Threatened to hurt you or someone you care about & 0.05 & $\begin{array}{c}-0.02 \\
(0.01)\end{array}$ & $\begin{array}{c}-0.01 \\
(0.01)\end{array}$ & $\begin{array}{c}-0.01 \\
(0.01)\end{array}$ \\
\hline Ignored you or was indifferent towards you & 0.23 & $\begin{array}{c}-0.05 \\
(0.03)\end{array}$ & $\begin{array}{c}-0.05 \\
(0.03)\end{array}$ & $\begin{array}{r}-0.05 \\
(0.03)\end{array}$ \\
\hline Humiliated or insulted you in front of others & 0.16 & $\begin{array}{c}-0.03 \\
(0.02)\end{array}$ & $\begin{array}{c}-0.03 \\
(0.03)\end{array}$ & $\begin{array}{c}-0.03 \\
(0.02)\end{array}$ \\
\hline \multicolumn{5}{|l|}{ Panel C. Physical and/or sexual violence } \\
\hline Pushed you or shook you or threw something at you & 0.13 & $\begin{array}{c}-0.03 \\
(0.02)\end{array}$ & $\begin{array}{r}-0.04 \\
(0.02)\end{array}$ & $\begin{array}{r}-0.04 \\
(0.02)\end{array}$ \\
\hline Slapped you or twisted your arm & 0.11 & $\begin{array}{c}-0.04 \\
(0.02)\end{array}$ & $\begin{array}{r}-0.04 \\
(0.02)\end{array}$ & $\begin{array}{r}-0.04 \\
(0.02)\end{array}$ \\
\hline Hit you with his fist or something else that could hurt you & 0.09 & $\begin{array}{c}-0.02 \\
(0.02)\end{array}$ & $\begin{array}{c}-0.02 \\
(0.02)\end{array}$ & $\begin{array}{c}-0.02 \\
(0.02)\end{array}$ \\
\hline Kicked you or dragged you & 0.06 & $\begin{array}{c}-0.01 \\
(0.02)\end{array}$ & $\begin{array}{r}-0.02 \\
(0.02)\end{array}$ & $\begin{array}{r}-0.02 \\
(0.02)\end{array}$ \\
\hline Tried to choke or burn you & 0.04 & $\begin{array}{c}-0.02 \\
(0.01)\end{array}$ & $\begin{array}{r}-0.02 \\
(0.01)\end{array}$ & $\begin{array}{r}-0.02 \\
(0.01)\end{array}$ \\
\hline Attacked you with a gun, knife, or other weapon & 0.01 & $\begin{array}{c}0.00 \\
(0.01)\end{array}$ & $\begin{array}{c}0.00 \\
(0.01)\end{array}$ & $\begin{array}{c}0.00 \\
(0.01)\end{array}$ \\
\hline Threatened you with a gun, knife, or other weapon & 0.01 & $\begin{array}{c}0.00 \\
(0.01)\end{array}$ & $\begin{array}{c}0.01 \\
(0.01)\end{array}$ & $\begin{array}{c}0.01 \\
(0.01)\end{array}$ \\
\hline Physically forced you to have sexual intercourse & 0.05 & $\begin{array}{c}-0.01 \\
(0.01)\end{array}$ & $\begin{array}{c}-0.02 \\
(0.01)\end{array}$ & $\begin{array}{c}-0.02 \\
(0.01)\end{array}$ \\
\hline Forced you to do something sexual that you found degrading & 0.03 & $\begin{array}{c}0.00 \\
(0.01)\end{array}$ & $\begin{array}{c}0.00 \\
(0.01)\end{array}$ & $\begin{array}{c}0.00 \\
(0.01)\end{array}$ \\
\hline
\end{tabular}

Notes: For each IPV indicator listed, treatment effects of pooled treatment are reported in columns 2-4. Standard errors in parentheses are clustered at the cluster level. Basic controls include baseline value of the outcome variable (when available) and dummy for province stratum. Extended controls include baseline female characteristics (whether the woman is head of household, whether she is married, whether she has secondary education, whether she is Colombian, whether she is indigenous, whether she is Afro-Ecuadorian, whether she is employed, whether she owns the house, and her age); partner characteristics (whether partner has secondary education, his age); household characteristics (number of children 0-5 years old, number of children 6-14 years old, wealth quartiles); baseline value of outcome variable (when available), and dummy for province stratum. Observations $=1,226$. 
Table 4-Impact of Treatment Modalities on IPV Measures

\begin{tabular}{|c|c|c|c|}
\hline & No controls & Basic controls & Extended controls \\
\hline \multicolumn{4}{|c|}{ Panel A. Controlling behaviors } \\
\hline Food treatment & $\begin{array}{c}-0.06 \\
(0.05)\end{array}$ & $\begin{array}{c}-0.05 \\
(0.05)\end{array}$ & $\begin{array}{c}-0.06 \\
(0.04)\end{array}$ \\
\hline Cash treatment & $\begin{array}{c}-0.09 \\
(0.04)\end{array}$ & $\begin{array}{c}-0.08 \\
(0.04)\end{array}$ & $\begin{array}{c}-0.08 \\
(0.04)\end{array}$ \\
\hline Voucher treatment & $\begin{array}{c}-0.06 \\
(0.04)\end{array}$ & $\begin{array}{c}-0.06 \\
(0.04)\end{array}$ & $\begin{array}{c}-0.06 \\
(0.03)\end{array}$ \\
\hline$p$-value: Food $=$ Voucher & 0.94 & 0.83 & 0.97 \\
\hline$p$-value: Cash $=$ Voucher & 0.35 & 0.55 & 0.56 \\
\hline$p$-value: Food $=$ Cash & 0.50 & 0.50 & 0.66 \\
\hline \multicolumn{4}{|l|}{ Panel B. Emotional violence } \\
\hline Food treatment & $\begin{array}{c}-0.05 \\
(0.05)\end{array}$ & $\begin{array}{c}-0.05 \\
(0.04)\end{array}$ & $\begin{array}{c}-0.05 \\
(0.04)\end{array}$ \\
\hline Cash treatment & $\begin{array}{c}-0.06 \\
(0.04)\end{array}$ & $\begin{array}{c}-0.06 \\
(0.04)\end{array}$ & $\begin{array}{c}-0.05 \\
(0.04)\end{array}$ \\
\hline Voucher treatment & $\begin{array}{c}-0.01 \\
(0.04)\end{array}$ & $\begin{array}{c}-0.03 \\
(0.04)\end{array}$ & $\begin{array}{r}-0.02 \\
(0.04)\end{array}$ \\
\hline$p$-value: Food $=$ Voucher & 0.50 & 0.68 & 0.44 \\
\hline$p$-value: Cash $=$ Voucher & 0.18 & 0.43 & 0.40 \\
\hline$p$-value: Food $=$ Cash & 0.75 & 0.82 & 0.94 \\
\hline \multicolumn{4}{|c|}{ Panel C. Physical and/or sexual violence } \\
\hline Food treatment & $\begin{array}{c}-0.06 \\
(0.04)\end{array}$ & $\begin{array}{r}-0.07 \\
(0.04)\end{array}$ & $\begin{array}{r}-0.08 \\
(0.04)\end{array}$ \\
\hline Cash treatment & $\begin{array}{c}-0.04 \\
(0.04)\end{array}$ & $\begin{array}{c}-0.05 \\
(0.03)\end{array}$ & $\begin{array}{c}-0.05 \\
(0.03)\end{array}$ \\
\hline Voucher treatment & $\begin{array}{c}-0.04 \\
(0.03)\end{array}$ & $\begin{array}{c}-0.06 \\
(0.03)\end{array}$ & $\begin{array}{c}-0.06 \\
(0.03)\end{array}$ \\
\hline$p$-value: Food $=$ Voucher & 0.52 & 0.71 & 0.54 \\
\hline$p$-value: Cash $=$ Voucher & 0.96 & 0.73 & 0.87 \\
\hline$p$-value: Food $=$ Cash & 0.57 & 0.52 & 0.46 \\
\hline
\end{tabular}

Notes: Standard errors in parentheses are clustered at the cluster level. Basic controls include baseline value of the outcome variable and dummy for province stratum. Extended controls include baseline female characteristics (whether the woman is head of household, whether she is married, whether she has secondary education, whether she is Colombian, whether she is indigenous, whether she is Afro-Ecuadorian, whether she is employed, whether she owns the house, and her age); partner characteristics (whether partner has secondary education, his age); household characteristics (number of children 0-5 years old, number of children 6-14 years old, wealth quartiles); baseline value of outcome variable, and dummy for province stratum. Observations $=1,226$.

\section{Robustness}

We present results from different robustness checks in the online Appendix. In particular, we show that results are robust to linear probability models (Appendix Table B.2), and bounding our treatment estimates to address potential issues of nonrandom sample selection (Appendix Table B.3). To bound our estimates we follow Lee (2009) and construct worst-case scenarios by assuming that women who select into the sample because of treatment (marginal women) are at the very top or very 
bottom of the distribution ${ }^{11}$ Thus, trimming the upper and lower tails of the distribution of the outcome variable by the proportion of marginal women yields bounds on the treatment effects for women who select into the survey irrespective of the treatment assignment. Appendix Table B.3 reveals tight bounds on the pooled treatment estimates and the modality specific estimates, which is not surprising given that the difference in non-missing observations between the treatment and control arms is quite small.

\section{Possible Mechanisms}

While our results provide strong evidence that transfers reduce IPV among the study population, the pathway or mechanism through which this occurs is unclear. Although we cannot disentangle the different mechanisms, we explore other factors that have changed as a result of the transfer that may have contributed to the decrease in IPV. In particular, we explore changes in a woman's bargaining power, labor allocation, and poverty. A few of these have been explored in companion papers, thus we only discuss and cite the results here.

To investigate whether the transfers lead to changes in women's bargaining power we analyze changes in the intra-household allocation of goods. Many studies have shown that cash transfer programs increase the share of food in total consumption, counter to Engel's Law, suggesting that households treat transfer income differently (Angelucci and Attanasio 2013; Attanasio, Battistin, and Mesnard 2012; Gilligan et al. 2014; Schady and Rosero 2008; Attanasio and Lechene 2014; Bobonis 2009). These studies argue that increases in food shares are likely due to shifts in intrahousehold bargaining that align resources more in a woman's favor. In our case, however, increases in food shares could also be explained by changes in preferences due to the nutrition trainings. Thus, we explore changes in child-related expenditures that would not be influenced by the trainings. In particular, we investigate impacts of the program on expenditures on children's clothes and compare it to changes in adult clothes. At baseline the Engel curve for child clothing is downward sloping in total consumption and straight in nonfood consumption; in contrast, the Engel curve for adult clothing is upward sloping (Appendix Figure A.1). Table 5 reveals that counter to the baseline Engel curve, transfers lead to a large and significant increase in expenditures and expenditure shares for child clothing, providing suggestive evidence that the allocation of resources has changed more in her favor. In contrast, we find no change in expenditure or expenditure shares for adult clothing. Two companion papers further explore the impact on women's bargaining power and find qualitative evidence that different domains (such as knowledge and participation) of

\footnotetext{
${ }^{11}$ The identifying assumption for calculating Lee bounds is monotonicity, which implies that treatment assignment affects sample selection only in one direction. In our case it is likely that treatment leads to households/women being found more easily at endline, and households/women being more willing to respond to the survey. Treatment is also likely to increase the probability that a woman is alone at the time of the interview, and thus be interviewed, since treatment leads to decreases in controlling behaviors of the spouse. The monotonicity assumption, however, might be violated if treatment leads to women not being in a relationship at endline and thus not interviewed at endline. However, only 1 percent of the eligible baseline sample were no longer in a relationship and thus not surveyed, and we find no evidence that treatment leads to higher rates of separation.
} 
Table 5-Impact of Pooled Treatment on Expenditure Shares

\begin{tabular}{|c|c|c|c|c|c|c|c|c|}
\hline & \multicolumn{4}{|c|}{ Adult clothes and shoes } & \multicolumn{4}{|c|}{ Child clothes and shoes } \\
\hline & $\begin{array}{c}=1 \\
\text { purchased }\end{array}$ & $\begin{array}{l}\log \\
\text { expenditures }\end{array}$ & $\begin{array}{c}\text { Expenditure } \\
\text { shares over } \\
\text { nonfood }\end{array}$ & $\begin{array}{c}\text { Expenditure } \\
\text { shares } \\
\text { over total }\end{array}$ & $\begin{array}{c}=1 \text { if } \\
\text { purchased }\end{array}$ & $\begin{array}{c}\log \\
\text { expenditures }\end{array}$ & $\begin{array}{c}\text { Expenditure } \\
\text { shares over } \\
\text { nonfood }\end{array}$ & $\begin{array}{l}\text { Expenditure } \\
\text { shares } \\
\text { over total }\end{array}$ \\
\hline Pooled treatment & $\begin{array}{c}0.06 \\
(0.04)\end{array}$ & $\begin{array}{c}0.15 \\
(0.18)\end{array}$ & $\begin{array}{c}0.01 \\
(0.02)\end{array}$ & $\begin{array}{c}0.00 \\
(0.01)\end{array}$ & $\begin{array}{c}0.07 \\
(0.03)\end{array}$ & $\begin{array}{c}0.22 \\
(0.11)\end{array}$ & $\begin{array}{c}0.03 \\
(0.02)\end{array}$ & $\begin{array}{c}0.01 \\
(0.00)\end{array}$ \\
\hline Observations & 1,226 & 1,226 & 1,219 & 1,219 & 1,226 & 1,226 & 1,219 & 1,219 \\
\hline $\begin{array}{l}\text { Mean of control } \\
\text { group at endline }\end{array}$ & 0.37 & 0.60 & 0.06 & 0.02 & 0.37 & 0.48 & 0.05 & 0.02 \\
\hline Basic controls & $\mathrm{X}$ & $\mathrm{X}$ & $\mathrm{X}$ & $\mathrm{X}$ & $\mathrm{x}$ & $\mathrm{X}$ & $\mathrm{X}$ & $\mathrm{X}$ \\
\hline Extended controls & $\mathrm{X}$ & $\mathrm{X}$ & $\mathrm{X}$ & $\mathrm{X}$ & $\mathrm{X}$ & $\mathrm{X}$ & $\mathrm{X}$ & $\mathrm{X}$ \\
\hline
\end{tabular}

Notes: Standard errors in parentheses are clustered at the cluster level. All estimations control for baseline female characteristics (whether the women is head of household, whether she is married, whether she has secondary education, whether she is Colombian, whether she is indigenous, whether she is Afro-Ecuadorian, whether she is employed, whether she owns the house, and her age); partner characteristics (whether partner has secondary education, his age); household characteristics (number of children 0-5 years old, number of children 6-14 years old, wealth quartiles); baseline value of outcome variable, and dummy for province stratum. Expenditure shares are constructed by dividing the value of the particular expenditure item over the value of nonfood expenditure or the value of total expenditures. Tobit models are used to estimate impacts on log expenditures and expenditure shares due to the large fraction of households that have zero expenditures on clothing.

empowerment have increased, although no impact was found on decision-making indicators collected at endline (Buller et al. forthcoming, Peterman et al. 2015).

We also explore whether transfers lead to changes in labor participation or time spent on domestic labor. If transfers lead to women and/or their husbands being home less frequently, this could reduce the frequency of IPV. Labor participation could also contribute to decreases in poverty related stress or improvements in bargaining power. However, if women engage in more work, or interact with new individuals outside the home, against the wishes of her partner, or in doing so, threaten existing power dynamics, IPV could increase. Table 6 reveals no change in labor force participation, but large increases in time spent on domestic labor for women (panel A) and increases in the probability that men participate in domestic labor (panel B). This is likely due to the fact that the training components of the program placed a large emphasis on family nutrition and cooking. While men's greater participation in domestic labor could be a sign of improved marital cohesion, her increased time spent on domestic labor could be a sign of either greater marital cohesion or increased work/stress.

Another pathway through which transfers may have decreased IPV is through reductions in poverty related stress and disputes. Although we did not collect direct measures of stress, a companion paper on food security shows large improvements in poverty related indicators such as increases in the total value of consumption and food security, irrespective of transfer modality (Hidrobo et al. 2014). In addition, a companion mixed methods paper on IPV further supports theories on stress, and shows that transfers lead to a decrease in tensions and disputes in the household, especially over daily food purchases, and an increase in happiness and locus of control (Buller et al. forthcoming). 
Table 6-Impact of Pooled Treatment on Labor Participation

\begin{tabular}{|c|c|c|c|c|c|c|c|}
\hline & $\begin{array}{c}\text { Worked in } \\
\text { agriculture } \\
\text { on household } \\
\text { land }\end{array}$ & $\begin{array}{c}\text { Worked in } \\
\text { agriculture, } \\
\text { salaried labor }\end{array}$ & $\begin{array}{l}\text { Worked in } \\
\text { non- } \\
\text { agriculture, } \\
\text { salaried labor }\end{array}$ & $\begin{array}{c}\text { Worked } \\
\text { independent, } \\
\text { non- } \\
\text { agriculture } \\
\text { labor }\end{array}$ & $\begin{array}{l}\text { Worked in } \\
\text { the last } \\
\text { six months }\end{array}$ & $\begin{array}{l}\text { Engaged in } \\
\text { domestic } \\
\text { labor in last } \\
\text { two weeks }\end{array}$ & $\begin{array}{l}\text { Hours worked } \\
\text { in domestic } \\
\text { labor in a } \\
\text { typical day }\end{array}$ \\
\hline \multicolumn{8}{|l|}{ Panel A } \\
\hline Pooled treatment & $\begin{array}{c}0.00 \\
(0.01)\end{array}$ & $\begin{array}{c}0.01 \\
(0.01)\end{array}$ & $\begin{array}{c}-0.03 \\
(0.02)\end{array}$ & $\begin{array}{c}0.02 \\
(0.02)\end{array}$ & $\begin{array}{c}-0.01 \\
(0.03)\end{array}$ & $\begin{array}{c}0.01 \\
(0.01)\end{array}$ & $\begin{array}{c}0.78 \\
(0.25)\end{array}$ \\
\hline Observations & 1,226 & 1,226 & 1,226 & 1,226 & 1,226 & 1,226 & 1,226 \\
\hline $\begin{array}{l}\text { Mean of control group } \\
\text { at endline }\end{array}$ & 0.01 & 0.05 & 0.19 & 0.13 & 0.37 & 0.98 & 5.63 \\
\hline Basic controls & $\mathrm{X}$ & $\mathrm{X}$ & $\mathrm{X}$ & $\mathrm{X}$ & $\mathrm{X}$ & $\mathrm{X}$ & $\mathrm{X}$ \\
\hline \multirow[t]{2}{*}{ Extended controls } & $\mathrm{X}$ & $\mathrm{X}$ & $\mathrm{X}$ & $\mathrm{X}$ & $\mathrm{X}$ & $\mathrm{X}$ & $\mathrm{X}$ \\
\hline & $\begin{array}{c}\text { Partner } \\
\text { worked in } \\
\text { agriculture } \\
\text { on household } \\
\text { land }\end{array}$ & $\begin{array}{c}\text { Partner } \\
\text { worked in } \\
\text { agriculture, } \\
\text { salaried labor }\end{array}$ & $\begin{array}{c}\text { Partner } \\
\text { worked in } \\
\text { non- } \\
\text { agriculture, } \\
\text { salaried labor }\end{array}$ & $\begin{array}{c}\text { Partner } \\
\text { worked in } \\
\text { independent, } \\
\text { non- } \\
\text { agriculture } \\
\text { labor }\end{array}$ & $\begin{array}{l}\text { Partner } \\
\text { worked in } \\
\text { the last } \\
\text { six months }\end{array}$ & $\begin{array}{c}\text { Partner's } \\
\text { hours worked } \\
\text { in a typical } \\
\text { week }\end{array}$ & $\begin{array}{l}\text { Partner } \\
\text { engaged in } \\
\text { domestic } \\
\text { labor in last } \\
\text { two weeks }\end{array}$ \\
\hline \multicolumn{8}{|l|}{ Panel B } \\
\hline Pooled treatment & $\begin{array}{c}0.00 \\
(0.02)\end{array}$ & $\begin{array}{c}0.02 \\
(0.02)\end{array}$ & $\begin{array}{c}-0.03 \\
(0.03)\end{array}$ & $\begin{array}{c}0.01 \\
(0.02)\end{array}$ & $\begin{array}{c}0.01 \\
(0.01)\end{array}$ & $\begin{array}{c}1.10 \\
(1.20)\end{array}$ & $\begin{array}{c}0.08 \\
(0.03)\end{array}$ \\
\hline Observations & 1,207 & 1,207 & 1,207 & 1,207 & 1,208 & 1,208 & 1,208 \\
\hline $\begin{array}{l}\text { Mean of control group } \\
\text { at endline }\end{array}$ & 0.04 & 0.20 & 0.58 & 0.17 & 0.95 & 45.19 & 0.50 \\
\hline Basic controls & $\mathrm{X}$ & $\mathrm{X}$ & $\mathrm{X}$ & $\mathrm{X}$ & $\mathrm{X}$ & $\mathrm{X}$ & $\mathrm{X}$ \\
\hline Extended controls & $\mathrm{X}$ & $\mathrm{X}$ & $\mathrm{X}$ & $\mathrm{X}$ & $\mathrm{X}$ & $\mathrm{X}$ & $\mathrm{X}$ \\
\hline
\end{tabular}

Notes: Standard errors in parentheses are clustered at the cluster level. All estimations control for baseline female characteristics (whether the woman is head of household, whether she is married, whether she has secondary education, whether she is Colombian, whether she is indigenous, whether she is Afro-Ecuadorian, whether she is employed, whether she owns the house, and her age); partner characteristics (whether partner has secondary education, his age); household characteristics (number of children 0-5 years old, number of children 6-14 years old, wealth quartiles); baseline value of outcome variable, and dummy for province stratum. Probit regressions conducted on binary indicators and OLS on continuous indicators. We do not include "hours worked in a typical week" as an outcome for women because the percentage of women working is very low. Similarly, we do not include "Partner's hours worked in domestic labor in a typical day" as an outcome because the percentage of partners who engaged in domestic labor is relatively low.

\section{Discussion and Conclusion}

Important policy questions around linkages between IPV and women's income remain unanswered due to lack of evidence and consensus on theories and mechanisms. With CT programs reaching approximately 750 million to 1 billion people in the developing world (Department of International Development (DFID) 2011), it is crucial that these programs understand how they may affect intra-household dynamics. The majority of current evidence linking income and IPV is from cross-sectional analysis and few studies are able to identify causal impacts.

This study uses a randomized design to investigate whether cash, vouchers, and food transfers targeted to women in poor urban areas and intended to reduce poverty and food insecurity also impact IPV. We find that transfers decrease the probability that a woman experiences controlling behaviors, and physical and/or sexual violence by 6 to 7 percentage points or approximately a 19 percent to 30 percent decrease from endline control means. These results are similar in magnitude to studies in Peru, Mexico, and Kenya, which find that CTs decreased physical IPV by 
5 to 11 percentage points (Bobonis, González-Brenes, and Castro 2013; Haushofer and Shapiro 2013; Perova 2010). Unlike in Mexico where decreases in physical violence are accompanied by increases in threats of violence, we find no evidence that partners use violence to forcefully extract transfers. Instead, we find decreases in violence that are similar in magnitude across transfer modality. Results from our study provide promising evidence that transfers not only have the potential to decrease multiple forms of IPV in the short-term, but also that cash - that is intended to reduce food insecurity - is just as effective as in-kind transfers in decreasing IPV.

We discuss potential pathways through which transfers impacted IPV, and find suggestive evidence that they improved female bargaining power, increased domestic labor of both husband and wife, and decreased poverty related stress. In particular, we find changes in the intra-household allocation of goods toward more child-friendly goods, which are more in line with a woman's preferences. We also find large increases in the probability that the husband engaged in domestic labor, which could be a sign of increased marital cohesion. For poverty related stress, we do not test directly decreases in stress but a companion paper shows that the transfers decreased poverty as measured by the value of consumption, and increased food security (Hidrobo et al. 2014). Preliminary evidence from Kenya's GiveDirectly evaluation on stress suggests that this is a potential pathway through which some transfer programs may affect IPV.

While we find no evidence that transfers are being extracted or leading to conflict within relationships, we cannot dismiss extraction or male backlash theories completely. The transfers were framed as part of a wider food security intervention and did not challenge traditional gender roles. Evidence shows that how the intervention is framed and labeled affects subsequent behavior (Benhassine et al. 2013, Buller et al. forthcoming). Consequently, transfers may not have led to extraction or conflict because they were perceived to be for the benefit of the entire household and household nutrition is typically thought of as being a domain traditionally controlled by women and mothers.

Our study's uniqueness must be taken into account when generalizing results to other contexts. First, the sample is a select population of urban poor living in Northern Ecuador, with a high percentage of Colombian born nationals. Moreover, since households receiving the government social protection program, $\mathrm{BDH}$, are excluded from the program, the demographics of the study sample exclude many households with young children. Second, the intervention and period of study was six months. The shortness of the intervention may have led beneficiaries to behave differently than they would have under a longer term program. However the short intervention period minimizes the possibility that impacts are due to selection into marriage or marriage dissolution through divorce. Finally, all transfer recipients participated in monthly nutrition education sessions, which may have had an empowering effect due to increased information and social networking with fellow recipients in their neighborhoods. Although we are not able to directly model the potential contribution of these nutrition sessions, our conclusions by modality would not be affected since all participants received identical exposure and information.

Although evaluations of CT programs are a promising starting place for research on IPV and female income, further experiments exploring dynamics with employment, 
micro-credit and other economic empowerment programs are equally important. Impacts from employment and micro-credit programs are likely to differ from those from CT programs, given that employment and micro-finance may have additional psychological and time allocation effects (Heath 2012). In addition, there is need for evidence on medium and long-term impacts, carefully accounting for changes in partnership dynamics, as evidence has shown that the relationship between IPV and income may fluctuate over time (Bobonis, Castro, and Morales 2015). Lastly, better data on conflict, stress, and bargaining power are needed in order to better understand the pathways through which transfers impact IPV.

\section{APPENDIX}

Table A.1-Intimate Partner Violence Questions

\begin{tabular}{|c|c|c|c|c|c|}
\hline \multirow{2}{*}{$\begin{array}{l}\text { When two people are married or } \\
\text { live together, they share good and } \\
\text { bad times. } \\
\text { Has your husband or partner } \\
\text { ever... }\end{array}$} & $\begin{array}{l}1=\text { Yes } \\
2=\text { No }>> \\
\text { Next item }\end{array}$ & $\begin{array}{l}\text { In the last } 6 \\
\text { months? } \\
1=\text { Yes } \\
2=\text { No }\end{array}$ & \multirow[t]{2}{*}{$\begin{array}{l}\text { Has your husband or partner } \\
\text { ever... }\end{array}$} & $\begin{array}{l}1=\text { Yes } \\
2=\text { No }>> \\
\text { Next item }\end{array}$ & $\begin{array}{l}\text { In the last } 6 \\
\text { months? } \\
1=\text { Yes } \\
2=\text { No }\end{array}$ \\
\hline & A & B & & A & B \\
\hline $\begin{array}{l}\text { T10 Accused you of being } \\
\text { unfaithful? (Controlling } \\
\text { behaviors) }\end{array}$ & & & $\begin{array}{l}\text { T28 Humiliated or insulted } \\
\text { you in front of others? } \\
\text { (Emotional violence) }\end{array}$ & & \\
\hline \multirow{2}{*}{$\begin{array}{l}\text { T11 Tried to limit your contact } \\
\text { with your family with the } \\
\text { objective of making you } \\
\text { feel bad? (Controlling } \\
\text { behaviors) }\end{array}$} & & & $\begin{array}{l}\text { T19 Tried to strangle or burn } \\
\text { you? (Physical violence) }\end{array}$ & & \\
\hline & & & $\begin{array}{l}\text { T20 Attacked you with a knife, } \\
\text { pistol, or other weapon? } \\
\text { (Physical violence) }\end{array}$ & & \\
\hline $\begin{array}{l}\text { T12 Humiliated or insulted you } \\
\text { with phrases such as "you } \\
\text { are worthless," "you never } \\
\text { do anything," "or "you } \\
\text { are stupid"? (Emotional } \\
\text { violence) }\end{array}$ & & & $\begin{array}{l}\text { T21 Threatened you with a } \\
\text { knife, pistol, or other } \\
\text { weapon? (Physical } \\
\text { violence) }\end{array}$ & & \\
\hline $\begin{array}{l}\text { T13 Threatened to leave you? } \\
\text { (Emotional violence) }\end{array}$ & & & $\begin{array}{l}\text { T22 Used physical force to force } \\
\text { you to have sexual relations } \\
\text { even though you did not } \\
\text { want to? (Sexual violence) }\end{array}$ & & \\
\hline $\begin{array}{l}\text { T14 Threaten to take away } \\
\text { your children? (Emotional } \\
\text { violence) }\end{array}$ & & & $\begin{array}{l}\text { T23 Forced you to perform } \\
\text { sexual activity that you } \\
\text { did not approve of? } \\
\text { (Sexual violence) }\end{array}$ & & \\
\hline $\begin{array}{l}\text { T24 Threatened to harm you or } \\
\text { someone you cared about? } \\
\text { (Emotional violence) }\end{array}$ & & & $\begin{array}{l}\text { T15 Pushes you, shakes you, or } \\
\text { throws something at you? } \\
\text { (Physical violence) }\end{array}$ & & \\
\hline $\begin{array}{l}\text { T25 Tried to limit your contact } \\
\text { with friends? (Controlling } \\
\text { behaviors) }\end{array}$ & & & $\begin{array}{l}\text { T16 Slapped or twisted your } \\
\text { arm? (Physical violence) }\end{array}$ & & \\
\hline $\begin{array}{l}\text { T26 Wanted to know where } \\
\text { you were at all times? } \\
\text { (Controlling behaviors) }\end{array}$ & & & $\begin{array}{l}\text { T17 Punched you or hit you with } \\
\text { something that could harm } \\
\text { you? (Physical violence) }\end{array}$ & & \\
\hline $\begin{array}{l}\text { T27 Ignored you or was } \\
\text { indifferent toward you? } \\
\text { (Emotional violence) }\end{array}$ & & & $\begin{array}{l}\text { T18 Kicked you or dragged } \\
\text { you? (Physical violence) }\end{array}$ & & \\
\hline
\end{tabular}


Panel A. Value of total consumption

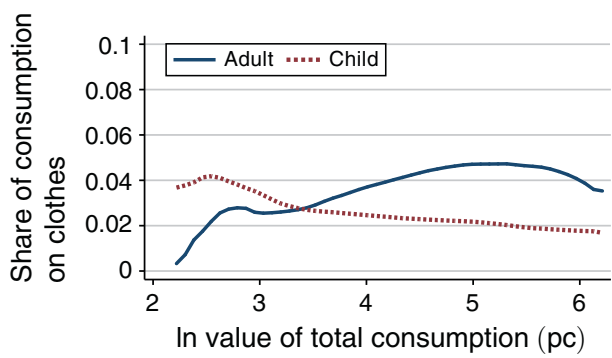

Panel B. Value of nonfood consumption

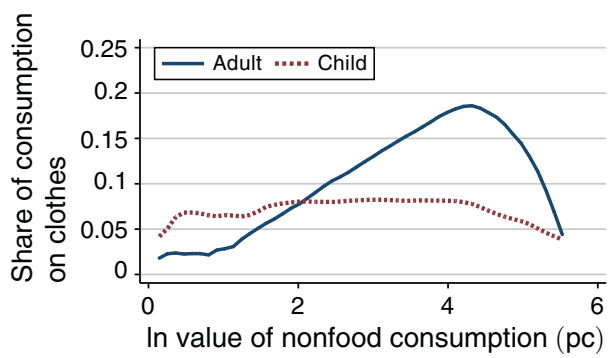

Figure A.1. Engel Curve for Clothes

Table A.2-Attrition Analysis by Baseline Characteristics

\begin{tabular}{|c|c|c|c|c|c|c|c|c|}
\hline & \multicolumn{3}{|c|}{ Control } & \multicolumn{3}{|c|}{ Treatment } & \multicolumn{2}{|c|}{ Difference } \\
\hline & $\begin{array}{l}\text { Attrited } \\
(1)\end{array}$ & $\begin{array}{c}\text { In } \\
\text { study } \\
(2)\end{array}$ & $\begin{array}{c}p \text {-value } \\
(3)\end{array}$ & $\begin{array}{c}\text { Attrited } \\
\text { (4) }\end{array}$ & $\begin{array}{c}\text { In } \\
\text { study } \\
(5)\end{array}$ & $\begin{array}{l}p \text {-value } \\
(6)\end{array}$ & $\begin{array}{c}\text { Columns } \\
1-4 \\
(7)\end{array}$ & $\begin{array}{c}p \text {-value } \\
(8)\end{array}$ \\
\hline \multicolumn{9}{|l|}{ Female characteristics } \\
\hline Head of household & 0.06 & 0.03 & 0.32 & 0.07 & 0.02 & 0.04 & -0.01 & 0.75 \\
\hline Born in Colombia & 0.60 & 0.39 & 0.00 & 0.46 & 0.34 & 0.03 & 0.14 & 0.11 \\
\hline Age & 35.48 & 35.29 & 0.91 & 33.86 & 34.66 & 0.48 & 1.62 & 0.39 \\
\hline Some secondary education or higher & 0.37 & 0.38 & 0.91 & 0.40 & 0.39 & 0.79 & -0.03 & 0.74 \\
\hline Married & 0.36 & 0.42 & 0.45 & 0.36 & 0.43 & 0.14 & 0.00 & 0.99 \\
\hline Indigenous & 0.06 & 0.03 & 0.41 & 0.08 & 0.04 & 0.16 & -0.02 & 0.62 \\
\hline Afro-Ecuadorian & 0.07 & 0.06 & 0.74 & 0.04 & 0.07 & 0.05 & 0.04 & 0.33 \\
\hline Worked in the last six months & 0.40 & 0.31 & 0.08 & 0.42 & 0.33 & 0.02 & -0.02 & 0.78 \\
\hline Sole owner of house & 0.04 & 0.04 & 0.87 & 0.05 & 0.05 & 1.00 & -0.01 & 0.87 \\
\hline \multicolumn{9}{|l|}{ Partner characteristics } \\
\hline Partner has some secondary education or higher & 0.40 & 0.36 & 0.50 & 0.44 & 0.39 & 0.30 & -0.04 & 0.67 \\
\hline Partner's age & 39.45 & 39.20 & 0.87 & 37.22 & 38.39 & 0.40 & 2.23 & 0.25 \\
\hline Partner was employed in the last six months & 0.94 & 0.96 & 0.55 & 0.92 & 0.96 & 0.06 & 0.02 & 0.54 \\
\hline Partner's hours worked in a typical week & 42.12 & 47.27 & 0.07 & 43.20 & 46.32 & 0.11 & -1.09 & 0.71 \\
\hline \multicolumn{9}{|l|}{ Household characteristics } \\
\hline Number of children $0-5$ years old in household & 0.63 & 0.72 & 0.34 & 0.66 & 0.75 & 0.14 & -0.03 & 0.78 \\
\hline Number of children 6-15 years old in household & 0.70 & 1.02 & 0.01 & 0.84 & 0.87 & 0.66 & -0.13 & 0.32 \\
\hline $\begin{array}{l}\text { Value of total monthly consumption per } \\
\text { capita (USD) }\end{array}$ & 113.23 & 107.32 & 0.53 & 104.98 & 106.31 & 0.84 & 8.25 & 0.47 \\
\hline House does not have rooms exclusively for sleeping & 0.06 & 0.13 & 0.07 & 0.24 & 0.15 & 0.04 & -0.18 & 0.00 \\
\hline Lifetime physical and/or sexual violence & 0.45 & 0.33 & 0.07 & 0.35 & 0.35 & 0.98 & 0.10 & 0.14 \\
\hline Controlling behaviors & 0.22 & 0.17 & 0.42 & 0.25 & 0.17 & 0.03 & -0.03 & 0.62 \\
\hline Emotional violence & 0.36 & 0.24 & 0.02 & 0.30 & 0.27 & 0.46 & 0.06 & 0.36 \\
\hline Physical and/or sexual violence & 0.22 & 0.12 & 0.13 & 0.20 & 0.18 & 0.45 & 0.02 & 0.80 \\
\hline
\end{tabular}

Notes: $p$-values are reported from Wald tests on the equality of means for those who attrited in treatment and control arms for each variable. Standard errors are clustered at the cluster level.

\section{REFERENCES}

Aizer, Anna. 2010. “The Gender Wage Gap and Domestic Violence.” American Economic Review 100 (4): 1847-59.

Angelucci, Manuela. 2008. "Love on the Rocks: Domestic Violence and Alcohol Abuse in Rural Mexico." B. E. Journal of Economic Analysis and Policy 8 (1).

Angelucci, Manuela, and Orazio Attanasio. 2013. "The Demand for Food of Poor Urban Mexican Households: Understanding Policy Impacts Using Structural Models." American Economic Journal: Economic Policy 5 (1): 146-78. 
Attanasio, Orazio, Erich Battistin, and Alice Mesnard. 2012. "Food and Cash Transfers: Evidence from Colombia." Economic Journal 122 (559): 92-124.

-Attanasio, Orazio P., and Valérie Lechene. 2014. "Efficient Responses to Targeted Cash Transfers." Journal of Political Economy 122 (1): 178-222.

Benhassine, Najy, Florencia Devoto, Esther Duflo, Pascaline Dupas, and Victor Pouliquen. 2013. "Turning a Shove into a Nudge? A 'Labeled Cash Transfer' for Education." National Bureau of Economic Research (NBER) Working Paper 19227.

Bloch, Francis, and Vijayendra Rao. 2002. "Terror as a Bargaining Instrument: A Case Study of Dowry Violence in Rural India." American Economic Review 92 (4): 1029-43.

Bobonis, Gustavo J. 2009. "Is the Allocation of Resources within the Household Efficient? New Evidence from a Randomized Experiment." Journal of Political Economy 117 (3): 453-503.

Bobonis, Gustavo J., Roberto Castro, and Juan S. Morales. 2015. "Conditional Cash Transfers for Women and Spousal Violence: Evidence of the Long-Term Relationship from the Oportunidades Program in Rural Mexico." Inter-American Development Bank (IDB) Working Paper IDB-WP-632.

-Bobonis, Gustavo J., Melissa González-Brenes, and Roberto Castro. 2013. "Public Transfers and Domestic Violence: The Roles of Private Information and Spousal Control." American Economic Journal: Economic Policy 5 (1): 179-205.

Buller, Ana Maria, Melissa Hidrobo, Amber Peterman, and Lori Heise. Forthcoming. "The way to a man's heart is through his stomach? A mixed methods study on causal mechanisms through which cash and in-kind food transfers decreased intimate partner violence." BMC Public Health.

-Chin, Yoo-Mi. 2012. "Male backlash, bargaining, or exposure reduction? Women's working status and physical spousal violence in India." Journal of Population Economics 25 (1): 175-200.

Department of International Development (DFID). 2011. Cash Transfer Evidence Paper. London: Department for International Development Policy Division.

Devries, K. M., J. Y. T. Mak, C. García-Moreno, M. Petzold, J. C. Child, G. Falder, S. Lim, et al. 2013. "The Global Prevalence of Intimate Partner Violence Against Women.” Science 340 (6140): $1527-28$.

-Ellsberg, Mary, Diana J. Arango, Matthew Morton, Floriza Gennari, Sveinung Kiplesund, Manuel Contreras, and Charlotte Watts. 2015. "Prevention of violence against women and girls: What does the evidence say?" Lancet 385 (9977): 1555-66.

Ellsberg, Mary, and Lori Heise. 2005. Researching violence against women: A practical guide for researchers and activists. Washington, DC: World Health Organization.

-Ellsberg, Mary, Lori Heise, Rodolfo Peña, Sonia Agurto, and Anna Winkvist. 2001. "Researching Domestic Violence Against Women: Methodological and Ethical Considerations." Studies in Family Planning 32 (1): 1-16.

-Eswaran, Mukesh, and Nisha Malhotra. 2011. "Domestic violence and women's autonomy in developing countries: Theory and evidence." Canadian Journal of Economics 44 (4): 1222-63.

-Farmer, Amy, and Jill Tiefenthaler. 1997. "An Economic Analysis of Domestic Violence." Review of Social Economy 55 (3): 337-58.

Gilligan, Daniel O., Melissa Hidrobo, John Hoddinott, Shalini Roy, and Ben Schwab. 2014. "Much ado about modalities: Multicountry experiments on the effects of cash and food transfers on consumption patterns." Paper presented at Agricultural and Applied Economics Association Annual Meeting, Minneapolis, MN, July 27-29.

Haushofer, Johannes, and Jeremy Shapiro. 2013. "Welfare Effects of Unconditional Cash Transfers: Evidence from a Randomized Controlled Trial in Kenya." https://www.princeton.edu/ joha/ publications/Haushofer_Shapiro_UCT_Analysis_Plan_2013.pdf.

Heath, Rachel. 2012. "Women's Access to Labor Market Opportunities, Control of Household Resources, and Domestic Violence.” World Bank Policy Research Working Paper 6149.

Heise, Lori. 2012. Determinants of partner violence in low and middle-income countries: Exploring variation in individual and population-level risk. $\mathrm{PhD}$ diss. London School of Hygiene and Tropical Medicine.

-Hidrobo, Melissa, and Lia Fernald. 2013. "Cash transfers and domestic violence." Journal of Health Economics 32 (1): 304-19.

Hidrobo, Melissa, John Hoddinott, Amy Margolies, Vanessa Moreira, and Amber Peterman. 2012. Impact evaluation of cash, food vouchers, and food transfers among Colombian refugees and poor Ecuadorians in Carchi and Sucumbios: Final Report. Washington, DC: International Food Policy Research Institute.

-Hidrobo, Melissa, John Hoddinott, Amber Peterman, Amy Margolies, and Vanessa Moreira. 2014. "Cash, food, or vouchers? Evidence from a randomized experiment in northern Ecuador." Journal of Development Economics 107: 144-56. 
Hidrobo, Melissa, Amber Peterman, and Lori Heise. 2016. "The Effect of Cash, Vouchers, and Food Transfers on Intimate Partner Violence: Evidence from a Randomized Experiment in Northern Ecuador: Dataset." American Economic Journal: Applied Economics. http://dx.doi.org/10.1257/ app. 20150048.

Hindin, Michelle J., Sunita Kishor, and Donna L. Ansara. 2008. Intimate Partner Violence among Couples in 10 DHS Countries: Predictors and Health Outcomes. United States Agency for International Development. Calverton, MD, December.

Hoddinott, John, and Lawrence Haddad. 1995. "Does Female Income Share Influence Household Expenditures? Evidence from Côte d'Ivoire." Oxford Bulletin of Economics and Statistics 57 (1): 77-96.

Instituto Nacional de Estadística y Censos (INEC). 2011. Encuesta nacional de relaciones familiares y violencia de genero contra las mujeres. Quito, Ecuador: Secretaría Nacional de Planificación y Desarrollo.

Lee, David S. 2009. "Training, Wages, and Sample Selection: Estimating Sharp Bounds on Treatment Effects." Review of Economic Studies 76 (3): 1071-1102.

-Lundberg, Shelly, and Robert A. Pollak. 1993. "Separate Spheres Bargaining and the Marriage Market." Journal of Political Economy 101 (6): 988-1010.

-Manser, Marilyn, and Murray Brown. 1980. "Marriage and Household Decision-Making: A Bargaining Analysis." International Economic Review 21 (1): 31-44.

McElroy, Marjorie B., and Mary Jean Horney. 1981. "Nash-Bargained Household Decisions: Toward a Generalization of the Theory of Demand." International Economic Review 22 (2): 333-49.

McKenzie, David. 2012. "Beyond baseline and follow-up: The case for more T in experiments." Journal of Development Economics 99 (2): 210-21.

Perova, Elizaveta. 2010. "Buying out of abuse: How changes in women's income affect domestic violence.” Unpublished.

Perova, Elizaveta, and Renos Vakis. 2013. Improving Gender and Development Outcomes through Agency: Policy Lessons from Three Peruvian Experiences. Washington, DC: World Bank.

Peterman, Amber, Benjamin Schwab, Shalini Roy, Melissa Hidrobo, and Daniel Gilligan. 2015. "Measuring Women's Decisionmaking: Indicator Choice and Survey Design Experiments from Cash and Food Transfer Evaluations in Ecuador, Uganda, and Yemen.” International Food Policy Research Institute (IFPRI) Discussion Paper 01453.

Pronyk, P. M., J. R. Hargreaves, J. C. Kim, L. A. Morison, G. Phetla, C. Watts, J. Busza, et al. 2006. "Effect of a structural intervention for the prevention of intimate-partner violence and HIV in rural South Africa: A cluster randomised trial." Lancet 368 (9551): 1973-83.

Quisumbing, Agnes R., and John A. Maluccio. 2000. Intrahousehold Allocation and Gender Relations: New Empirical Evidence from Four Developing Countries. Washington, DC: International Food Policy Research Institute.

Schady, Norbert, and José Rosero. 2008. "Are cash transfers made to women spent like other sources of income?" Economics Letters 101 (3): 246-48.

-Straus, Murray A. 1979. "Measuring Intrafamily Conflict and Violence: The Conflict Tactics (CT) Scales." Journal of Marriage and the Family 41 (1): 75-88.

Tauchen, Helen V., Ann Dryden Witte, and Sharon K. Long. 1991. "Domestic Violence: A Nonrandom Affair." International Economic Review 32 (2): 491-511.

Thomas, Duncan. 1997. "Incomes, expenditures, and health outcomes: Evidence on intrahousehold resource allocation." In Intrahousehold Resource Allocation in Developing Countries: Models, Methods, and Policy, edited by Lawrence Haddad, John Hoddinott, and Harold Alderman, $142-64$. Baltimore: Johns Hopkins University Press.

World Food Programme-Ecuador. 2011. Report on the Cash and Voucher project: Quarterly Report of Monitoring, May-July 2011. Quito, Ecuador: World Food Programme.

World Health Organization (WHO). 2001. Putting women first: Ethical and safety recommendations for research on domestic violence against women. Geneva: Department of Gender and Women's Health.

World Health Organization (WHO). 2013. Global and regional estimates of violence against women: Prevalence and health effects of intimate partner violence and non-partner sexual violence. Geneva: World Health Organization. 